\title{
Fact Finding in the English Court of Chancery: A Rebuttal
}

\section{John H. Langbein ${ }^{\dagger}$}

In a recent article in this Journal Harold Chesnin and Geoffrey Hazard presented a breathtaking thesis: The English Court of Chancery lacked the power to "decide fact issues itself . . . until some time after 1800, at least a decade after the effective date of the Seventh Amendment." 1 By "fact issues" the authors mean "contested issues of fact." "The authors hypothesize that the office of the Lord Chancellor was not originally endowed with the power to decide questions of fact, though it assumed that power by the nineteenth century." 3 This might mean that the Seventh Amendment requires a federal court sitting in equity to submit disputed questions of fact to a jury. ${ }^{4}$

Because their thesis is couched as an interpretation of the right to jury trial under the American Constitution, it has a potential for mischief in our courts and requires a swift rebuttal. Section I of this article shows that the historical sources contradict the authors' contentions. First, the Court of Chancery did indeed have and exercise fact finding power. Second, when the court delegated factual disputes for trial at law, the verdict was advisory and nonbinding. Section II points to the larger context of the relations between equity and law for an understanding of the Chancery's practice of referring issues of fact to common law trial.

\section{I}

Chesnin and Hazard report that their research has disclosed but one case instancing Chancery fact finding before the 19th century. In Bennet $v$. Vade, "the Court of Chancery apparently undertook itself

$\dagger$ Professor of Law, University of Chicago.

1. Chesnin \& Hazard, Chancery Procedure and the Seventh Amendment: Jury Trial of Issues in Equity Cases before 1791, 83 YALE L.J. 999, 1000 (1974) [hereinafter cited as Chesnin \& Hazard].

2. Id.

3. Id. at 1018 .

4. Id. at 1020. The Seventh Amendment provides that: "In suits at common law, where the value in controversy shall exceed twenty dollars, the right of trial by jury shall be preserved, and no fact tried by a jury shall be otherwise reexamined in any court of the United States, than according to the rules of common law." U.S. CoNST. amend. VII.

5. 2. Atk. 324, 26 Eng. Rep. 597 (1742). 
to determine the facts in the case of an allegedly insane testator."6 Actually, such evidence exists in ample quantity in the 18th-century Chancery reports. We need go no further than the volume in which Bennet $v$. Vade appears, the second volume of Atkyns' Reports. ${ }^{7}$

In Clarke v. Periam, ${ }^{8}$ the plaintiff sued to establish a bond securing to her an annuity of sixty pounds. The bond had been given her praemium pudicitiae, that is, to compensate her for the loss of her chastity. The defendant cross-claimed for cancellation of the obligation on grounds amounting to mistake in the inducement: "the plaintiff was a lewd woman, and a common prostitute." Ten witnesses deposed to the plaintiff's "unblemished character, previous to her acquaintance with Periam." For the defendant four witnesses swore on the basis of hearsay "to particular instances of lewdness . . . ." The court had to determine whether to permit the defendant "to prove the plaintiff guilty of acts of lewdness with a particular person, one Mr. Abingdon, before she was acquainted with Periam." Lord Chancellor Hardwicke ruled that the evidence was admissible, and he decreed upon the merits for the defendant. Hence, the contested issue of fact upon which the case turned was not referred to jury trial, but was decided by the Chancellor.

In Hine $v$. Dodd, the question was whether the defendant mortgagee had notice of the plaintiff's judgment debt against the mortgagor before the execution of the mortgage, in which event the plaintiff would have been entitled to a priority. Lord Hardwicke sifted the depositions ${ }^{10}$ and concluded that the defendant had merely "suspicion

6. Chesnin \& Hazard, supra note 1, at 999 n.2.

7. J. AtKyns, Reports of Cases ARgued and Determined in the High Court of Chancery, in the Time of Lord Chancellor Hardwicke (1767). For an earlier example of equity fact finding, see Okeduer v. Tettus (1675), 1 LORD NotTINGHaM's Chancery CASES 236, 237-38 (D. Yale ed. 1957) [hereinafter cited as Notringham].

8. 2 Atk. 333, 26 Eng. Rep. 603 (1741).

9. 2 Atk. 275, 26 Eng. Rep. 569 (1741).

10. The first evidence is Elizabeth Hine; but $I$ cannot lay any great stress upon her deposition, it is only an account of a conversation at the Devil tavern, where the plaintiff was present with Dodd and Burton, the agent of Dodd: the next is Thomas Price, who swears that the plaintiff told Burton, he knew of this judgment before Dodd's mortgage, and that defendant Dodd did not deny what the plaintiff said to Burton, but then he does not swear that Dodd heard what the plaintiff said.

The most material evidence is Sarah Hine, who was present with the plaintiff Burton and Dodd on the 18th of June 1738, at a meeting in order to adjust all matters in difference between them: she swears that the plaintiff then charged Dodd with notice of the judgment, prior to the execution of the mortgage, and that Dodd answered, it was true he knew of the judgment, but that he knew, at the same time, it was not registered, and what were acts of parliament for, unless they were effectually observed.

Undoubtedly this is a material evidence, but then it is only one witness against the answer of the defendant; it is true his answer is very loose, by referring from 
of notice, though a strong suspicion, not sufficient to justify the court" denying to him the priority he had established by complying with the register act. ${ }^{11}$

The issue in Walker $\%$. Walker ${ }^{12}$ was whether a charge on the defendant's copyhold estate was conditioned upon the plaintiff's unperformed oral promise to surrender his copyhold estate to the defendant. Lord Hardwicke held that the Statute of Frauds was avoided and concluded on the merits that the plaintiff's claim was "rebutted by the equity set up by the defendant." His decisions followed an explicit review of the evidence. ${ }^{13}$ In Yates $v$. Hambly, ${ }^{14}$ the Chancellor declared that the defendant "is intitled to an absolute estate [free of trust, in five houses], though it is an exceeding dark transaction; but yet it is not proper to direct an issue to try a trust [by jury trial in a common law court], nor do I remember any instance of it . . . " In Read v. Read, ${ }^{15}$ Lord Hardwicke, after suggesting his view of the probable merits on the state of the evidence, ${ }^{16}$ remitted a case of alleged fraud for a factual inquiry before a master in equity.

These cases from a single volume of Chancery reports make it manifest that the Chancellor had and exercised the power to resolve contested issues of fact. Lord Hardwicke put the matter with some emphasis in a later decision, Ex parte Oursell, ${ }^{17}$ where the question

one answer to another; but in the last he swears to his belief, that he did not know of the judgment till after the mortgage was executed.

So that here is barely the evidence of a defendant's confession, in contradiction to his answer, and contrary to a positive act of parliament made to prevent any temptation to perjury from contrariety of evidence.

Some stress has been laid upon Burton's being an agent of Dodd, and likewise the solicitor in the cause of $H$ ine and Proof; but as this suit was two years before Dodd's mortgage, it will not affect Dodd with notice.

2 Atk. at 275, 26 Eng. Rep. at 569.

11. 7 Ann. c.20 (1708).

12. 2 Atk. 98, 26 Eng. Rep. 461 (1740).

13. The material part of the defendant's evidence is, that in three days after John Walker's surrender, the plaintiff declared, I have John Walker fast, but he shall not have me fast.

Neither the fact is charged by the defendant's witnesses, nor the credit of the witnesses impeached by the plaintiff's evidence.

The steward of the court examined for the plaintiff, and concerned in the transaction, swearing, that at or before the time of the surrender, he never heard of the agreement insisted on by the defendant, is a manifest evasion, and a negative pregnant that he heard of it after the surrender.

Id. at 100, 26 Eng. Rep. at 462.

14. 2 Atk. 360, 26 Eng. Rep. 618 (1742).

15. 2 Atk. 16, 26 Eng. Rep. 406 (1739).

16. Lord Hardwicke thought it a very strong suspicion of fraud in this case, that two separate bonds should be given upon the same day for different sums, and one of them just double the penalty of the other, where one bond for the whole sum was the most proper and natural method: his Lordship for this reason directed an inquiry before a Master into the consideration of the bonds.

2 Atk. at 16, 26 Eng. Rep. at 406.

17. Amb. 297, 298, 27 Eng. Rep. 200, 201 (1756). 
was whether a letter written by Oursell amounted to an appropriation of certain bills of exchange: "It is a matter of fact, not of law. I am satisfied on the evidence. It amounts to an appropriation . . . The same pattern of equity fact finding prevailed at the time the Seventh Amendment was adopted. ${ }^{18}$

In the light of these authorities, how are we to understand the "line of reports" cited by Chesnin and Hazard for their contention that Chancery's power to "decide fact issues itself was not firmly established in England until some time after $1800 \ldots$. .?10 They quote the Chancellor's pronouncement in Webb v. Claverden:20 "This court will not determine a fraud, in procuring a will, without directing a trial at law ...." And they cite Bates $\%$. Graves ${ }^{21}$ and various early 19 th-century cases to the same effect. One line of cases shows the Chancellor confidently finding facts, while another seems to hold that he cannot do what we have seen him doing.

This conflict is considerably less mysterious than first appears. Chesnin and Hazard's "line of reports"22 is drawn primarily from a recognized category of suits involving fraud in which Chancery lacked subject matter jurisdiction over what was otherwise a characteristic sphere of equity. ${ }^{23}$

[I]n certain cases, as of fraud in obtaining a will, whether of personal estate, or real estate, the proper remedy is exclusively vested in other Courts; in wills of personal estate in the Ecclesiastical Courts; and in wills of real estates in the Courts of Common Law. ${ }^{24}$

Even when the claim was fraud, the Chancery was without authority to determine the validity of the execution of a will. This jurisdictional

18. Lampert v. Lampert, I Ves. Jr. 21, 30 Eng. Rep. 210 (1789) (fraud alleged and proved by plaintiff's evidence over defendant's denial); Ex parte Saunderson, 2 Cox 197, 30 Eng. Rep. 91 (1789) (master in equity authorized to examine the parties orally after interrogatories produced "very strong contradictions"); Coote v. Boyd, 2 Bro. C.C. 522, 29 Eng. Rep. 286 (1789) (parol evidence received and declared insufficient to prove that a legacy in a codicil duplicating a legacy in the will was meant to be a second and distinct bequest); Cox v. Peele, 2 Bro. C.C. 334, 29 Eng. Rep. 186 (1788) (defendant's evidence insufficient to defeat bill for foreclosure).

19. Chesnin \& Hazard, supra note 1 , at 1000 .

20. 2 Atk. 424, 26 Eng. Rep. 656 (1742).

21. 2 Ves. Jr. 287, 30 Eng. Rep. 637 (1793).

22. Chesnin \& Hazard, supra note 1 , at $1000 \&$ n.5.

23. Pemberton v. Pemberton, 11 Ves. Jr. 50, 32 Eng. Rep. 1006 (1805); Bates v. Graves, 2 Ves. Jr. 287, 30 Eng. Rep. 637 (1793); Webb v. Claverden, 2 Atk. 424, 26 Eng. Rep. 656 (1742); cf. Bennet v. Vade, 2 Atk. 324, 26 Eng. Rep. 597 (1742).

24. I J. Story, CoMmentaries on EQUity JURISPRUdence as ADMINISTERed in ENGLAND AND AMERICA 194 (1836) (footnotes omitted). For an earlier and more comprehensive statement of the rule, cited by Story, see $1 \mathrm{~J}$. Fonblanque, A Trearise of EQUiTY $63-65$ (1793); $c f$. id. at $12 \mathrm{n} ; 2$ id. at 324. 
exclusion was imposed on the Chancery by the House of Lords in 1727 in Kerrich v. Bransby. ${ }^{25}$ Similarly, the other cases cited by Chesnin and Hazard also involved want of jurisdiction. ${ }^{26}$

Chesnin and Hazard have, therefore, taken cases in which the Court of Chancery was wholly without subject matter jurisdiction and read them to say that within Chancery's proper jurisdiction the court lacked authority to resolve disputes of fact. In truth, where Chancery possessed subject matter jurisdiction, it was never obliged to refer a fact dispute to common law trial. Chesnin and Hazard are indeed correct to observe that Chancery frequently did remit disputes of fact and of law to trial or opinion in the common law courts. These references, however, were for the convenience and at the discretion of the Chancellor. He could when he wished decide even questions of common law. ${ }^{27}$

25. 7 Bro. P.C. 437, 3 Eng. Rep. 284 (1727). This rule had been anticipated in earlier Chancery practice. For early instances of deference to ecclesiastical or common law jurisdiction in suits raising the validity of wills, see Cocken v. Dary (1585), Browne v. Ricards (1600); Handall v. Lyttle John (1602), in C. Monro, Acta CancellariaE 547, 761,769 (1847); and Vicars v. Vicars (1677), in 2 Notringham, supra note 7, at 546. See also Tigh v. Tigh (1618), in J. RITCHe, Cases Decided BY LoRd Bacon, 1617-21, at 84 (1932), cited by Chesnin \& Hazard, supra note 1, at 1006 \& n.32. Originally intended to reduce jurisdictional conflict with the common law and ecclesiastical courts, the exclusion survived into modern American practice. Gifford, Will or No Will? The Effect of Fraud and Undue Influence on Testamentary Instruments, 20 CoLUM. L. REV. $862,868-69$ (1920).

26. The authors cite Kemp v. Pryor, 7 Ves. Jr. 237, 32 Eng. Rep. 96 (1802), which was a commercial case where the court found no equity jurisdiction and left the plaintiff to his remedies at law. The authors also cite two cases involving the payment of tithes, Warden of St. Paul's v. Morris, 9 Ves. Jr. 155, 32 Eng. Rep. 561 (1803); O'Connor v. Cook, 6 Ves. Jr. 665, 31 Eng. Rep. 1247 (1802). Both concerned the problem of establishing a so-called modus-whether by custom the tithes incident to particular ecclesiastical livings had been commuted into different modes of payment. The modus issue was the subject of a Kerrich-type rule of automatic reference to jury trial:

Where the title to tithes is clearly made out, the court of chancery, or the [equity side of the] court of exchequer, decrees an account; and where a modus or real composition is pleaded and supported by reasonable evidence, it is the practice to di. rect an issue at law before they decree against the common law right of the parson. 1 H. Maddock, A Treatise on the Princilles and Practice of THE High Court of CHANCERY 85 (1817). The rationale was the same as for Kerrich itself-deference to the jurisdiction primarily responsible. Story, citing to Morris among other modus cases, says:

The peculiaxities, belonging to the law of tithes and the doctrines respecting moduses

... do not in any important manner illustrate any of the general doctrines of Equity;

but turn upon considerations eminently of an ecclesiastical nature . . . .

1 J. STORY, supra note 24, at 495 . Only in cases governed by the Kerrich rule and in modus cases was reference to common law jury trial mandatory:

References from equity, except in the two cases of an heir, and of a rector, proceed

not of right, but of discretion, to satisfy the conscience of the court, concerning

doubts as to facts, or as to the law.

2. H. MADDOCK, supra, at 364 (footnotes omitted).

27. See D. Yale, Introduction, in 1 NortinghaM, supra note 7, at liii, and sources there cited. "It is quite clear that [Lord Nottingham's] regular practice when questions of law arose was to order a trial at law with directions to resort back to the court. Exceptionally, however, where he felt there was a potential injustice in such a course, he would depart
from it." 
We can illustrate the discretionary nature of the referrals by considering a situation that commonly led to referral: where the proofs consisted primarily of the defendant's sworn denial to the plaintiff's allegations, contradicted by the sworn deposition of one witness for the plaintiff. In some such cases "the court has doubted concerning the fact, and has directed a trial at law . . . "2s But Chancery decided many such cases itself. If there was no evidence beyond the conflicting statements, the plaintiff would lose because he had not sustained his burden of proof. In Alam $v$. Jourdan, ${ }^{29}$ decided in 1683, it is reported: "There being but one witness against the defendant's answer, the plaintiff could have no decree."

Where, however, the plaintiff adduced additional evidence to support the sworn testimony of his witness, the Chancellor could and did decree for him without ordering a trial at law. In Only v. Walker, ${ }^{30}$ the plaintiff sued for specific enforcement of an agreement to compose an $£ 84$ bond for $£ 29$. The defendant swore his denial of the agreement, which was proved for the plaintiff by a single witness. However, the plaintiff also proved that the defendant had endorsed the composition on the back of the bond "and some other circumstances to corroborate the evidence of the single witness." The court was willing, if the defendant wished, to refer the case to jury trial in a common law court. The defendant insisted that such a trial be framed to allow his answer in the Chancery proceedings to be read to the jury. (At common law the parties were still disqualified from testifying on account of interest.) Because the plaintiff's evidence in the Chancery suit was strong, the court was unwilling to give the defendant the privilege of common law trial on these especially favorable terms. "The defendant refusing to try it upon any other terms, his Honour decreed the agreement to be carried into execution . . . ." Janson $\%$. Rany $y^{31}$ is another case where the plaintiff supported his single witness "by a great number of circumstances," which moved Lord Hardwicke to decree in his favor without referring the disputed fact (prior payment of a bond) to jury trial.

When the Chancellor did refer a fact dispute to jury trial in a common law court, what force did the resulting verdict acquire? Chesnin and Hazard contend that "[a]pparently, the decision to reject a ver-

28. Glynn v. Bank of Eng., 2 Ves. Sr. 38, 42, 28 Eng. Rep. 26, 28 (1750) (Hardwicke, L.C.).

29. 1 Vern. 161, 23 Eng. Rep. 387 (1683).

30. 3 Atk. 407, 26 Eng. Rep. 1035 (1746).

31. 2 Atk. 140, 26 Eng. Rep. 488 (1740); cf. Walton v. Hobbs, 2 Atk. 19, 26 Eng. Rep. 409 (1739). 
dict, except in the most unusual circumstances, was regarded as beyond the scope of the Lord Chancellor's powers." 32 This incorrectly implies that the Chancellor's powers were narrowly limited. While verdicts were actually rejected only in unusual circumstances, this was a voluntary policy and did not result from a lack of Chancery power. Attorney-General $v$. Turner, ${ }^{33}$ decided in 1742 , illustrates the practice of rejecting verdicts. The question was the familiar one of the validity of a will, in this instance a will making a remainder gift to charitable trusts. The heir who would take on intestacy if the will were invalid contested the sanity of the testator. The Chancellor, who was obliged by the Kerrich rule to have the question of fact tried at common law, directed an issue in Common Pleas. The verdict was in favor of the will. The heir moved in Chancery (not in Common Pleas) for a new trial at law, which the Chancellor refused because the Chief Justice of Common Pleas "certified that he was well satisfied with the verdict." 34 The Chancellor declared the will proved and decreed the trusts. Thereafter ${ }^{35}$ the heir discovered important new evidence that the testator had indeed been insane (a letter to one of the trustees written by one of the witnesses to the will desiring not to be subpoenaed because he knew the testator was insane). The heir petitioned the Chancellor for a new trial at law, which the Chancellor directed on an issue in King's Bench. On this trial the verdict went against the validity of the will. It was certified to the Chancellor, who accepted it and vacated his previous decrees. One of the trustees petitioned for yet another new trial, which the Chancellor refused after the judges of King's Bench "informed him, that they were all well satisfied with the said verdict, and ... [the Chancellor] did not see any cause to

32. Chesnin \& Hazard, supra note 1 , at 1008 .

33. Amb. 587, 27 Eng. Rep. 382 (1742).

34. It was the practice of the common law judges to take notes on the proceedings they conducted. See, e.g., I Catalogue of Manuscripts in the Library of the Honourable SOCIETY OF THE INNER TEMPLE 48.49 (J. Davies ed. 1972) (the notes of one 18th century judge). When a common law verdict was challenged in subsequent Chancery proceedings, the Chancellor could procure a certificate from the trial judge concerning the evidence and the instructions at the trial. See, e.g., Faulconberg v. Peirce, Amb. 210, 27 Eng. Rep. 140 (1754). The Chancellor could also obtain this information even without a certificate. In Bates v. Graves, 2 Ves. Jr. 287, 30 Eng. Rep. 637 (1793), the Chancellor, with no certificate, consulted the notes of a trial judge who had died in the interval. Another way in which the Chancellor could be informed of the common law proceedings was by stipulation of the parties. Cleeve v. Gascoigne, Amb. 323, 27 Eng. Rep. 217 (1756). The use of any of these procedures by the Chancellor was discretionary.

35. There was another stage to the litigation not relevant to the point in text. The heir, following his initial defeat in Chancery, brought an action of ejectment. The Attorney-General, enforcer of charitable trusts, had the common law proceedings stayed and had the heir perpetually enjoined from pursuing the ejectment action. 
grant a new trial of the said issue ...."Hence, even in a case in which the Kerrich rule required the Chancellor to send the fact dispute to common law trial, he could reject the verdict and order a new trial if he were dissatisfied with the verdict.

In the vast majority of cases the Kerrich rule did not apply. The Chancellors delegated fact disputes to common law trial for their own convenience, and the verdict was advisory only. On "equity reserved" the Chancellor had discretion to enter a decree implementing the verdict, to grant a new trial, or to enter a decree contrary to the verdict. Because it would have been senseless to order up jury verdicts and then to disregard them capriciously, the normal practice in equity was to adopt the common law verdict as conclusive of the facts, unless the verdict was questioned for cause.

The language of the Chancery judges is insistent that they retained control over verdicts taken in aid of their jurisdiction. In Coker $v$. Farwell, decided in $1729,{ }^{36}$ the Master of the Rolls said:

$[\mathrm{I}] \mathrm{n}$ matters of equity, an issue directed, is only directed to try the fact, to inform the conscience of the Court, and not to try the right of the parties, as where the matter in issue is a legal title; and one verdict may be sufficient to inform the conscience of the Court; and the Court, if satisfied of the fact, upon the depositions in the cause, need not direct an issue at all, but make a decree without it.

Similarly, in Stace v. Mabbot, decided in $1754,{ }^{37}$ the Chancellor stated:

But this court directs issues to be tried at law to inform the conscience of the court as to facts doubtful before; and therefore expects in return such a verdict and on such a case, as shall satisfy the conscience of the court to found a decree upon . . . . Undoubtedly therefore it is in the discretion of the court to grant new trials, if they think fit, if there is a ground for it upon the circumstances here; and the question is, whether there is so or not .... I cannot say that my conscience is satisfied as to the grounds and truth of the evidence, upon which this verdict is given.

The only limitation which the Chancery put upon its discretion in recognizing verdicts was the practice of granting one retrial auto-

36. I Swans. 403, 36 Eng. Rep. 435, 436 (1729). Accord, Peacock v. Mackericher, Dick. 434, 21 Eng. Rep. 338 (1770); Stace v. Mabbot, 2 Ves. Sr. 552, 28 Eng. Rep. 352 (1754); Richards v. Symes, 2 Atk. 319, 26 Eng. Rep. 594 (1742). The Chancellor in Coker $v$. Farwell agreed with this statement of the Master of Rolls. I Swans, at 403, 36 Eng. Rep. at 436 .

37. 2 Ves. Sr. 552-53, 28 Eng. Rep. $352-53$ (1754). 
matically when the effect of the first verdict was to disinherit an heir. ${ }^{38}$

Chancery's control over these verdicts involved not only the power to order new trials, but also the power to decree contrary to the verdict. Of course Chancery rarely exercised that power-not because the power was lacking, but because there was seldom any reason to use it. Chesnin and Hazard record with disbelief Lord Hardwicke's recollection of a case in which, notwithstanding many verdicts in favor of a deed, "Lord King made a decree to have it brought into court and cancelled here, the former trials not being to the satisfaction of the court."39 As significant as the case itself is Lord Hardwicke's later approving citation of it. There is a similar precedent, from 1675, Inglett v. Inglett. ${ }^{40}$

It was the essence of the referral procedure that the verdicts were not binding on the Chancellor. We do well to conclude with the emphatic language used by Lord Hardwicke on the occasion of ordering a new trial on an issue. "[T] than courts of law can; for if a verdict is not against evidence, as this was not, court of law cannot grant a new trial; but Court of Equity will, in order to have justice done: for the verdict must be such as will satisfy the conscience of this court." 41

\section{II}

The deterioration of Chancery procedure is a celebrated theme of English legal history. The Court of Chancery was established in the 14th century because of its superior modes of procedure and proof. ${ }^{42}$

38. Id. See G. Gilbert, The History and Practice of the High Court of Chancery 164 (1758) (written before Gilbert died in 1726):

[I] $\mathrm{t}$ is taken as a fundamental rule of equity, that the inheritance of an heir at law, shall not be bound down by one single trial, he may have another trial for asking for; but if the second verdict goes against him, he will not be intitled to a third trial for asking for ....

39. Stace v. Mabbot, 2 Ves. Sr. $\mathbf{5 5 2}, 554,28$ Eng. Rep. 352, 353 (1754).

40. 1 Notringham, supra note 7, at 189. The case had twice been sent to verdict at common law before Lord Nottingham's tenure as Chancellor. Nottingham offered to allow the winner to retain the judgment on onerous conditions, "or otherwise let loose the judgment without regard to the subsequent trials so often directed by the Court whereof I saw no necessity nor any great use." In the end Nottingham did set aside the verdicts, remitted to a master in equity, and decreed on the basis of the master's report with modifications. 2 Id. at 449.

41. Faulconberg v. Peirce, Amb. 210, 27 Eng. Rep. 140 (1754). See also Richards

v. Symes, 2 Atk. 319, 26 Eng. Rep. 594 (1742), where the Chancellor said:

But then it is said, and materially too, that there is a difference between issues at common law, and issues directed by this court, because the intent of it here is only to inform the conscience of the court, and therefore not tied down to the same strictness and regard for verdicts as courts of common law.

42. Avery, The History of the Equitable Jurisdiction of the Chancery before 1460, 42 Bulx. Inst. Hist. Research 129, 134-35 (1969). 
By the 19th century the court had become the setting for Bleak House. ${ }^{43}$ "The middle classes were alarmed at its very name, for it swallowed up smaller fortunes with its delays, its fees, its interminable paper processes." 44

Chancery was a one-judge court. ${ }^{45}$ "It was this feature ... that accounted for the delays in the chancery and the sense of helplessness felt by those driven to litigate there."40 Although the Chancellor had been aided by the Master of the Rolls since the 17 th century, ${ }^{47}$ it was not until the middle third of the 19th century, in the shadow of oncoming fusion, that the judicial manpower of Chancery was significantly increased. 48

At least since the 16th century, the Chancellor had a jurisdiction vastly larger than his resources. To administer it required massive delegation. Dawson has shown how the court employed local laymen as examining commissioners; how this begot ever more complex interrogatories prepared by the parties' lawyers; and how this in turn led to heavy reliance on the pleadings "as a substitute form of proof." 49 It was a "breakdown of the Chancery's ordinary modes of proof"so that forced the court to delegate its functions. While the 16th century Chancery encouraged the submission of cases to arbitration, ${ }^{51}$ referral to common law trial became the Chancery's regular device for delegation of factual disputes during the 17th and 18th centuries. ${ }^{52}$ The practice was probably encouraged in the later 17 th century by the sud. den development in common law procedure of judicial power to set aside unfounded jury verdicts. ${ }^{53}$

At a time when Chancery's fact-finding procedure had become as "futile [as ever] existed in any mature legal system," "54 common law

43. C. Dickens, Bleak House (1853).

44. Bowen, Progress in the Administration of Justice in the Victorian Period, in 1 Select Essays in Anglo-American Legal History 516, 527 (Ass'n of Am. Law Schools ed. 1907).

45. Indeed, Chancery was something less than a "one-man court," because the Chancellor was a major political officer with many responsibilities outside the court. The phrase is Plucknett's. T. Plucknet, A Concise History of the Common Law 689 (5th ed. 1956).

46. S. Milsom, Historical Foundations of the Common law 87 (1969).

47. T. PluCKNetr, supra note 45, at 209. The judicial authority of the Master of the Rolls was finally resolved by statute in the 18th century, 3 Gro. 2, c.30 (1730) (preserving the Lord Chancellor's right of review).

48. T. PluCKNetT, supra note 45, at 209-10.

49. J. DAWSON, A History OF LAY JUdGes $154-58$ (1960).

50. Id. at 159 .

51. Id. at 163.69.

52. T. PLuCKNETT, supra note 45 , at 210-11.

53. See E. Jenks, According to the Evidence, in CAMBridge Leal EsSAYs 191 (1926); T. Plucknetr, supra note 39 , at 135-36; $2 \mathrm{~W}$. TIDd, The Practice of the Courts of King's Bench and Common Pleas, in Personal Actions 926-27 (6th ed. 1817).

54. 9 W. Holdsworth, A History of English Law 353 (1926). 
jury trial was at the acme of its efficiency: rapid ${ }^{55}$ and as yet unburdened by the extended voir dire or by most of the modern evidentiary barriers. The worst feature of civil jury procedure, the testimonial disqualification of parties for interest, the Chancellor could order dispensed. ${ }^{56}$

This article has presented numerous authorities showing that Chancery engaged in fact finding and adjudication. In many other cases, disputes were referred to common law trial. Chancery delegated cases not because it lacked the power to decide them, but because it lacked the means. The more burdened jurisdiction borrowed the facilities of the less burdened, while always "reserving equity," that is, retaining ultimate authority over the delegated cases.

If that relationship is thought to bear on the Seventh Amendment, it should incline us in our day to do as the English did in 1791-to channel our cases to the more efficient and less burdened fact finder. Today that is no longer the jury.

55. See J. CockbuRn, A History of English Assizes 137-38 (1972). Lord Nottingham provides some evidence of the dispatch with which jury verdicts could be procured. An issue was directed in Hide $v$. Seymor in May of 1678; the verdict had been taken and further proceedings were being had in November of that year. 2 NotringhaM, supra note 7 , at 650,709 . In Hatcher $v$. Curtis a verdict was ordered in January 1680 and proceedings after verdict occurred in October of that year. Id. at 781-82, 845-46.

56. See Bauerman v. Radenius, 7 T.R. 663, 667-68, 101 Eng. Rep. 1186, 1188-89 (K.B. 1798). 


\section{The Yale Law Journal}

Volume 83, Number 8, July 1974

\begin{tabular}{|c|c|c|}
\hline $\begin{array}{l}\text { David A. Martin } \\
\text { Editor-in-Chief }\end{array}$ & $\begin{array}{l}\text { R. Hale Andrews, JR. } \\
\text { PhIlip C. BobbitT } \\
\text { LaURA J. Corwin }\end{array}$ & $\begin{array}{l}\text { Holly E. Kendig } \\
\text { Charles H. Montange } \\
\text { Stephen R. MysLiwiec }\end{array}$ \\
\hline MARK I. LEVY & Alan B. Loughnan & LEWIS T. STEVENS \\
\hline Executive Editor & $\begin{array}{c}\text { Article \& Book Review } \\
\text { Editors }\end{array}$ & $\begin{array}{c}\text { JOHN P. WHEELER II } \\
\text { Note Editors }\end{array}$ \\
\hline T. Du & & ANDREW H. COHN \\
\hline Manag & & oject Edito \\
\hline & D. & \\
\hline 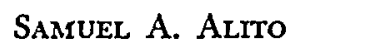 & WAL & MA \\
\hline o & OWEN E. MACBRIDE & ROBERT \\
\hline oY L. BRoOKS & ELliot E. MAXWELL & MICHAEL L. TABAK \\
\hline NFORD $B$. & Charles A. Patrizia & ZELINSKY \\
\hline ILLIAM & & ers Paulsso \\
\hline
\end{tabular}

Secretaries to the Editors M. Olive Butterfield, Pamela Willmott

\section{Student Contributors to This Issue}

Charles H. Montange, Informed Consent and the Dying Patient

William A. Fletcher, Standing to Sue for Members of Congress

Richard B. Levin, Union Authorization Cards: Linden's Peacemaking Potential

Frank G. Washington, Toward Community Ownership of Cable Television 